\title{
Back for Good
}

\section{Reforms in Legalization and Amnesty Programmes in Malaysia}

\author{
Choo Chin Low | ORCID: 0000-0003-3159-9311 \\ History Section, School of Distance Education, Universiti Sains Malaysia, \\ Penang, Malaysia \\ lowc@usm.my
}

\begin{abstract}
This article suggests that legalization and amnesty programmes have not been able to reduce undocumented migration in Malaysia for two reasons. First, the programmes merely serve as a registration tool that provides foreign workers with short-term work permits and as a surveillance tool to keep track of foreign workers. Second, the temporary work permits granted are no substitute for a migrant-labour management policy in addressing the acute shortage of low-skilled workers. Despite the introduction of these programmes, undocumented migrants have continued to exist because employers prefer to hire undocumented workers in their 'race to the bottom' in terms of costs, and the workers are dependent on their employers and agents as the gatekeepers of their legal immigration status. In 2016 and 2019, the Malaysian government introduced two reforms to its legalization and amnesty programmes: it eliminated outsourcing of the process in the Rehiring Programme (2016) and barred repatriated migrants from re-entering the country under the Back for Good amnesty programme (2019). Though these reforms have partially addressed the limitations of the previous programmes, they have not addressed the root cause of migrant labourers working without proper documentation.
\end{abstract}

\section{Keywords}

amnesty - immigration control - labour market - legalization - undocumented migration - voluntary repatriation 
In July 2019, the Malaysian government announced a new amnesty programme called Back for Good (B4G) to reduce the number of undocumented migrants in the country. This five-month programme was managed directly by the Immigration Department (August-December 2019), without any intermediaries, in order to eliminate labour exploitation. It envisaged the sending back of all undocumented immigrants permanently, rather than facilitating their return through legal channels, as intended by past amnesty initiatives. As reflected in the title of the programme, the deportees were permanently repatriated and barred from re-entering Malaysia for an indefinite period. ${ }^{1}$ Similar to past amnesty efforts, the $\mathrm{B} 4 \mathrm{G}$ programme, which allowed undocumented workers to be repatriated voluntarily without any legal action being taken against them, was not taken up widely because employers did not cooperate. Foreign workers missed the deadline because they were not released by their employers, even though sufficient time was allowed for the amnesty. ${ }^{2}$

By granting an amnesty, the Malaysian government aimed to reduce undocumented migration and deportation costs. The amnesty programme (also known as voluntary return) allowed undocumented foreign workers to leave the country without prosecution (Garcés-Mascareñas 2012:96-8). 'Amnesty' refers to the state's pardoning of immigration violations by the undocumented immigrants. Undocumented immigrants who surrender to the authorities have to leave the country under the voluntary repatriation programmes, but do not face legal penalties for violating immigration regulations, subject to paying a fine. Those who did not participate in the amnesty exercise and were later caught would be arrested, charged, and deported (Kassim and Mat Zin 2011:212). The term 'legalization' or 'regularization' refers to the granting of a work permit for legal employment purposes. It does not connote the granting of any

1 M. Kumar, 'Fresh bid to send illegal workers back for good', Star Online, 19-7-2019. https://www .thestar.com.my/news/nation/2019/o7/19/fresh-bid-to-send-illegal-workers-back-for-good\#g MhZhwGXAuX652g6.99 (accessed 10-8-2019); Cindi Loo, 'Back-for-Good amnesty programme for overstaying foreigners', Sun Daily, 18-7-2019. https://www.thesundaily.my/local/ back-for-good-amnesty-programme-for-overstaying-foreigners-DD1126849 (accessed 10-8-20 19); Chandan Kumar Mandal, 'Hundreds of undocumented Nepali workers return from Malaysia after availing general amnesty', Kathmandu Post, 10-10-2020. https://kathmandupost .com/national/2020/01/10/hundreds-of-undocumented-nepali-workers-return-from -malaysia-after-availing-general-amnesty (accessed 10-7-2020).

2 Nisha David, 'Malaysia detains hundreds of undocumented migrants as amnesty program ends', Benar News, 2-1-2020. https://www.benarnews.org/english/news/malaysian/malaysia -immigration-01022020164814.html (accessed 10-7-2020). 
residence or citizenship status to foreign workers or their dependents. Legalization is possible for foreign workers who have overstayed after the expiry of their work permits and/or those who have entered illegally. ${ }^{3}$ Legalization aims to eliminate underground employment, allows undocumented migrants to be included in formal employment, and enables them to obtain protection under the labour laws (World Bank 2013:104-8). The policy of legalization functions as a 'post-entry enforcement' measure that grants a temporary legal status to undocumented workers, without having to bring in new workers (Kaur 2014:353-4).

The use of amnesty and legalization as a policy instrument to reduce the number of undocumented workers in Malaysia raises many concerns, including whether it tackles the root cause of undocumented migration and whether it is beneficial for the undocumented foreign workers. Legalizing undocumented workers by giving them a one- or two-year work permit may not work, because temporary work permits are no substitute for a proper migrant-worker policy. The shortage of workers in the industries in which they are employed is a reality to be reckoned with and migrant workers are a crucial part of these industries' needs. Without a comprehensive policy that covers recruitment to placement, migrant workers continue to be treated as 'expendable factors of production.4 The presence of undocumented workers is very high, despite the continuous cycles of legalization. The legalization exercises only managed to register and legalize them. Through these exercises, these newly registered foreign workers were provided with a work permit after they had obtained travel documents from their respective embassies and paid all the necessary fees. However, their legal status was only temporary. If they failed to renew their work permits annually, the legalized workers would once again become undocumented. A World Bank report titled 'Immigration in Malaysia' stated that the legalization exercises 'did not provide a permanent solution to the problem of irregular foreigners in the country' (World Bank 2013:122).

Undocumented migration has continued to be a major problem, as the structural demand for cheap labour in Malaysia by various sectors cannot be met by the local workforce. Employers' preference for migrant workers to fill the ${ }_{3} \mathrm{D}$ (dirty, dangerous, and difficult) positions, which is indicated by their payment of low wages and their disinclination to hire Malaysian workers, explains the heavy economic reliance on the foreign workforce (Lee 2017:567). Underground

3 Penyata rasmi Parlimen, Dewan Rakyat, 22-11-2018, pp. 18-9. https://www.parlimen.gov.my/ files/hindex/pdf/DR-22112018.pdf (accessed 7-7-2019).

4 Glorene A. Das, 'Temporary work permits for migrants can't substitute proper policy', Malaysiakini, 2-11-2020. https://www.malaysiakini.com/letters/549101 (accessed 19-11-2020). 
employment is a reality to be reckoned with due to employers' inclination to hire undocumented foreign workers in their 'race to the bottom' practices. Firms compete against one another and pay the lowest wages to improve cost competitiveness. This unhealthy competition leads to the suppression of overall national wages, which affects the wages of low-skilled local workers and discourages locals from working in medium- and low-skilled jobs (Ang, Murugasu and Chai 2018:4). The government only seems to have a loose grip on dealing with the heavy influx of foreign workers, which also raises the question of whether the economy could survive without them. While the country needs low-wage foreign workers for economic and industrial development, the current situation is no longer focused on meeting the structural needs of the economy but rather on profit-making. Many employers are hiring foreign workers to reduce their operational costs. ${ }^{5}$

Civil society organizations opposed amnesty because it did not address the root causes of irregularity: foreign workers working without proper documentation. Repatriating workers to their home countries and bringing in new workers would, in the long run, generate new market demand, opening more doors for private agencies, traffickers, and smugglers to bring in more labourers. Amnesty was therefore a 'cosmetic solution' to undocumented migration, according to Adrian Pereira, founder of the North South Initiative, a socialjustice non-governmental organization (NGO). ${ }^{6}$ The immigrant community and civil society organizations urged the government to address the root causes of undocumented migration: the profit-driven activities of private companies to which the process was outsourced, deception by labour agents, fraud by agents handling the legalization programme, the existence of human trafficking syndicates, and labour exploitation by employers. ${ }^{7}$ The Migrant Workers' Right to Redress Coalition urged the government to review its 'tough, no-nonsense stand on illegal immigrants' ${ }^{8}$ Post-amnesty enforcement operations were criticized by migrant rights organizations for targeting migrant workers. They were concerned about human rights violations during the large-

5 Malaysian Trades Union Congress, 'Malaysia too lenient on illegal foreign workers', 29-12-2017. http://www.mtuc.org.my/malaysia-too-lenient-on-illegal-foreign-workers/ (accessed 10-8-20 19).

6 Trinna Leong, 'Activists blast amnesty plan for illegal workers', Straits Times, 10-8-2019 https:// www.straitstimes.com/asia/se-asia/activists-blast-amnesty-plan-for-ill (accessed 10-8-2019).

7 Civil Society Organisations, 'Immigration raids make criminals out of victims', Malaysiakini, 4-7-2018. https://www.malaysiakini.com/letters/432752 (accessed 10-8-2019).

8 Migrant Workers' Right to Redress Coalition, 'Flawed set-up for workers', Star Online, 7-8-2019. https://www.thestar.com.my/opinion/letters/2019/o8/o7/flawed-set-up-for-workers (accessed 10-7-2020). 
scale raids that were conducted, which often involved public round-ups on city streets and warrantless raids on private homes. Malaysia's security operations mainly penalized immigrants, rather than the errant employers or trafficking syndicates. ${ }^{9}$

The ongoing tension between the economic demand for cheap labour versus the security need for immigration control is reflected in the continuous cycles of legalization, amnesty, and prosecution of undocumented migrants since 1989. The Ministry of Home Affairs (мона) has acknowledged that the policy of amnesty and legalization could send the signal that it is acceptable to bring in foreign workers without permission, and that they would eventually be granted legal status. However, enforcement operations and forced deportation alone could not reduce the number of undocumented migrants if amnesty and voluntary repatriation were not undertaken. ${ }^{10}$ The unresolved issue of labour migration has resulted in large numbers of both undocumented and documented labour migrants. In 2014, the Hansard report indicated that there were 6.7 million foreign workers in the country, out of which 2.1 million possessed a valid permit and 4.6 million of them were undocumented. ${ }^{11}$ In December 2018, the мона declared that it would cease the regularly implemented amnesty programme. Undocumented migrants were now viewed as disregarding the law of the state and deliberately overstaying. Deputy Minister Azis Jamman stated: "The frequent holding of the legalization programme can become a bad culture for the country.'12

Since 2016, the government has introduced two changes to the legalization and amnesty programmes. First, it has replaced the private companies to which the work was outsourced with government-appointed immigration vendors in the Rehiring and Relocation Programme (Program Penggajian dan Penempatan Semula Pendatang Asing Tanpa Izin) and E-Card (E-Kad) Programme. Second, it has sent back undocumented immigrants permanently, as in the $\mathrm{B} 4 \mathrm{G}$ amnesty programme; this contrasted with all previous amnesty programmes, which allowed deportees to return as legal workers. These reforms were signific-

9 Amnesty International Malaysia, 'Malaysia: Halt ongoing crackdown, protect migrant workers (public statement)', 3-7-2018. https://www.amnesty.my/malaysia-halt-ongoing -crackdown-protect-migrant-workers/ (accessed 10-7-2020).

10 Penyata rasmi Parlimen, Dewan Rakyat, 30-10-2018, p. 75. https://www.parlimen.gov.my/ files/hindex/pdf/DR-30102018.pdf (accessed 7-7-2019).

11 Penyata rami Parlimen, Dewan Rakyat, 24-11-2014, p. 72. https://www.parlimen.gov.my/ files/hindex/pdf/DR-24112014.pdf (accessed 7-7-2019).

12 'Deputy home minister: No more regular legalisation for illegals', New Straits Times, 12-122018. https://www.nst.com.my/news/government-public-policy/2018/12/439992/deputy -home-minister-no-more-regular-legalisation (accessed 10-8-2019). 
ant because they removed the commercial aspect from the process, addressed migrant welfare, and revamped foreign-worker management in the long run.

This article examines how the conflict between labour market needs and immigration control can lead to an inconsistent foreign-worker policy. Why were legalization and amnesty programmes unable to reduce undocumented migration? What have been the limitations of the legalization and amnesty programmes implemented since 1989? What changes have been introduced to these programmes to address their limitations since 2016? This research draws on qualitative data available from official documents, Hansard documents (2004-2018), online news, media statements by NGOs and trade associations, and secondary literature.

\section{The Tension between a Smooth Labour Market and Immigration Control}

There are two schools of thought about the Malaysian policy on managing foreign workers: the labour market thesis and the immigration control paradigm. According to the labour market thesis, the state approached foreign-worker management from an economic perspective. Inflows were regulated to 'maximize national economic benefit' due to the growing demand for cheap labour (Nesadurai 2013:99). Since the late 1970s, Malaysia has become a country of immigration for economic migrants from neighbouring countries. The growth of industrialization, coupled with expansion in the manufacturing, agricultural, plantation, construction, and service sectors, has resulted in local firms resorting to foreign labour, mainly from Indonesia (Kaur 2015:79). In parallel to the development of the Malaysian-Indonesian migration industry, the influx of undocumented migrants was sustained by lucrative people-smuggling businesses, a profitable black-market document industry, and corruption in both countries (Jones 2000:35, 89). Undocumented migration inflows persisted due to the commercialization of the migration industry, acute labour market shortages, demand for cheap labour, wage differentials between Malaysia and its neighbours, the lack of administrative capacity to manage labour migration, a weak recruitment system with the extension of brokers, the activities of recruitment agencies and social networks, the illegal entry of immigrants arranged by syndicates, and the privatization of recruitment (Garcés-Mascareñas 2012:49, 72; Kassim 2014:18-9; Kaur 2014:345, 350).

The strong pull factor encouraged the illegal entry of migrant workers. Indonesian migrants perceived that illegal entry routes were 'more practical', faster, and cheaper compared to the costly, time-consuming, and complex bureau- 
cratic procedures of the legal channels. Undocumented migrants have greater flexibility to choose their employers and work without being tied to a specific employer. Under the rigid employer-sponsored work permit system, workers are not allowed to change jobs (Nah 2012:501-2; World Bank 2013:121). The state allows employers to exercise disciplinary power over foreign workers in terms of recruitment, the renewal of immigration permits, and the reporting of absconded foreign workers. Employers can unilaterally cancel the immigration permits of their workers and keep their passports (in conflict with the Passport Act 1966). The sponsorship-based immigration system subjects migrant workers to the goodwill of their employers based on their compliance. Those not complying are at risk of having their immigration permits cancelled, resulting in the loss of their legal status (Nah 2012:494, 498).

Many migrant workers in Malaysia arrived or became undocumented as a result of the lucrative business of the labour migration trade. Labour migration recruitment, management, and enforcement are based on profit-making motives. The profit-orientated migration industry involves multiple state and non-state actors in the countries of origin and destination, resulting in fraud, exploitation, and excessive recruitment. ${ }^{13}$ The high legal migration costs charged by private agents encouraged existing documented workers to overstay to pay off their debt and potential new workers to enter the country illegally. Migrants using the legal channel are burdened with considerable debt upon their arrival in Malaysia. Trapped in debt bondage, the migrants overstay beyond their employment period to continue working underground (World Bank 2015:57).

The Malaysian economy is highly dependent on foreign labourers, in the sense that the economy cannot survive without them. This is a big dilemma for Malaysia, as dependence on foreign workers affects the government's policy in managing immigrants. Foreign workers are needed in the economy but are not accepted as part of the national system. Although the government has implemented several policies to reduce this dependency, dependence on foreign workers continues (Dollah and Abdullah 2015:38). Labour-intensive industries rely on foreign labour to remain competitive. The high reliance on foreign workers has allowed the structural development of the economy without any disruption, even during times of economic crisis. This reliance is real; any disruption in the labour flow could undermine Malaysia's economic growth (Narayanan

13 Migrant Workers' Right to Redress Coalition, 'Flawed set-up for workers', Star Online, 7-82019. https://www.thestar.com.my/opinion/letters/2019/08/o7/flawed-set-up-for-workers (accessed 10-7-2020). 
and Lai 2005:51-2). However, this reliance on the foreign workforce in Malaysia has shifted from meeting a structural economic need to being one that ensures a cost-effective approach. Malaysian companies employ foreign workers to reduce operational costs. Foreign workers are highly preferred by employers as they do not require the same employment benefits as local workers. ${ }^{14}$

Migrant workers have not replaced local workers in the labour market, because migrant workers fill the jobs shunned by locals. The foreign workforce constitutes a significant segment of the Malaysian labour force and complements the educated local workforce. Between 1990 and the early 2000 , the share of foreign workers in the total labour force rose from $3.5 \%$ to $9.5 \%$ (World Bank 2015:31). While foreign workers are concentrated in low-skilled jobs, local workers are predominantly employed in semi-skilled and skilled occupations. In 2017 , foreign workers held $51 \%$ of low-skilled jobs, $17.3 \%$ of semi-skilled jobs, and $2.7 \%$ of skilled jobs (Khazanah Research Institute 2018:124-6). From 2010 to 2017 , the number of foreign workers increased from 1.683 million to 2.235 million. The share of foreign workers in the total workforce of Malaysia fluctuated around 14.9\% between 2010 and 2017 (Khazanah Research Institute 2018:120).

The Eleventh Malaysia Plan targets reducing the heavy reliance on lowskilled foreign workers by capping the proportion of foreign workers at $15 \%$ of the total workforce in 2020 . This target will be achieved through automation in labour-intensive activities in the agriculture, manufacturing, and construction sectors, which employ more than $30 \%$ of foreign workers. The transition to automation and mechanization is perceived as a move to reduce the reliance on human labour (Economic Planning Unit 2015: Chapter 5). The Ministry of Human Resources (МОнR) has initiated long-term measures, including introducing the minimum wage for foreign workers to reduce the dependence on low-skilled foreign workers, encouraging automation in the plantation and manufacturing sectors, encouraging the introduction of self-service systems in the service sector, promoting the use of Industrialized Building System technology in the construction sector, restricting the recruitment of foreign workers in sectors with a sufficient local-labour supply, and freezing the recruitment of foreign workers in some service sectors. ${ }^{15}$

The government has been unable to regulate labour market needs, because jobs traditionally filled by migrants in labour-intensive industries have not

14 Malaysian Trades Union Congress, 'Malaysia too lenient on illegal foreign workers', 29-122017. http://www.mtuc.org.my/malaysia-too-lenient-on-illegal-foreign-workers/ (accessed 10-8-2019).

15 Penyata rasmi Parlimen, Dewan Rakyat, 11-7-2013, pp. 4-5. https://www.parlimen.gov.my/ files/hindex/pdf/DR-11072013.pdf (accessed 7-7-2019). 
always been able to be replaced either by positions filled with local workers or automation. Reducing the state's dependence on foreign workers has not been achieved because employers continue to hire foreign labourers on salaries below the minimum wage of MYR 1,200 (as of 2020) and to suppress the salaries of local workers. The situation has discouraged employers from hiring foreign workers legally on the minimum wage and has discouraged Malaysian workers from taking on low-skilled jobs. Employers are not obliged to offer better employment packages to encourage local uptake and prefer to hire foreign workers. ${ }^{16}$

Government policy states that local workers are to be prioritized for employment opportunities and that the recruitment of foreign labour is restricted to particular economic sectors. Employers are required to inform the Department of Labour of any job vacancy to enable local jobseekers to fill the vacancy first. The employment of foreign workers is only allowed in six sectors; manufacturing, construction, plantations, services, agriculture, and foreign maids. ${ }^{17}$ Most of the foreign workers come from Indonesia, Nepal, Bangladesh, India and Myanmar (Table 1).

Despite the country's reliance on foreign workers since the 1970s, the state has not had the capacity and public resources to regulate the labour market. The management and recruitment of documented foreign labourers have been outsourced to private agencies with minimum state intervention (GarcésMascareñas 2012:102). The entry of workers was unregulated, with no mechanisms for legal labour recruitment where employers used private contractors to recruit workers. It was not until the 198 os that the state intervened in the labour market and sought to regulate migrant worker entry by concluding bilateral memoranda of understanding with countries of origin (Kassim and Mat Zin 2011:16-8; Kaur 2015:83-5). A Special Task Force on Foreign Labour was established in 1995 to regulate the labour market and directly manage labour recruitment. This was an attempt to eliminate the role of private agencies and centralize the function under the state's machinery, following widespread abuses by private employment agencies. However, these belated interventionist efforts failed, and the government resorted to private agencies (Jones 2000:29; Kaur 2014:349, 354).

16 'MTUC to Home and HR ministries: Address foreign workers issue together', New Straits Times, 23-6-2020. https://www.nst.com.my/news/nation/2020/06/6o2696/mtuc-home -and-hr-ministries-address-foreign-workers-issue-together (accessed 19-11-2020).

17 Kementerian Dalam Negeri, 'Dasar semasa penggajian pekerja asing'. http://www.moha .gov.my/index.php/ms/bahagian-pa-dasar-dasar-semasa/dasar-semasa-penggajian -pekerja-asing (accessed 17-12-2020). 


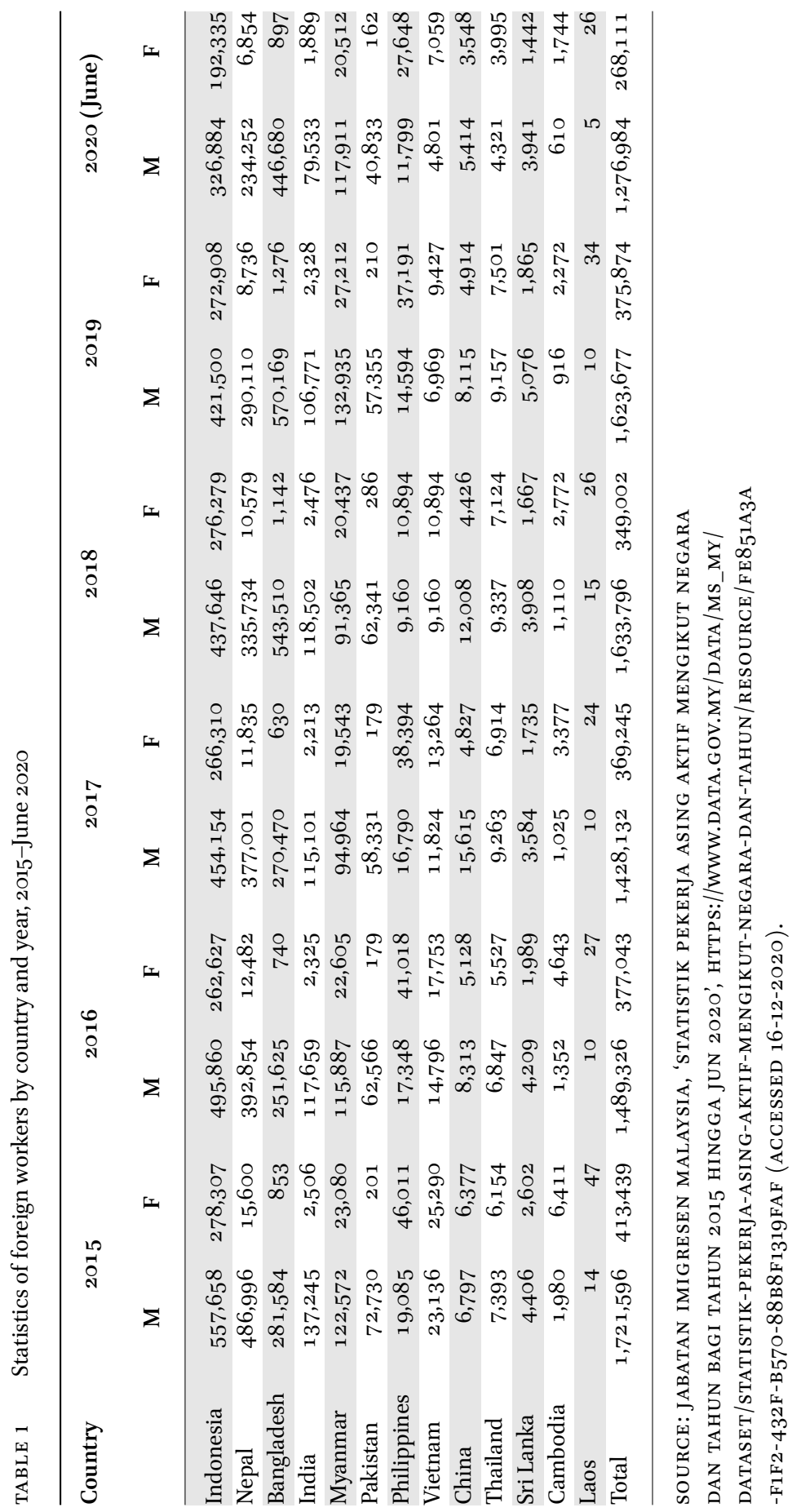


The immigration control paradigm suggests that labour migration policies have been influenced by national-security concerns. Migrant labour management is securitized as undocumented migration is perceived as a threat to Malaysia's national security (Arifianto 2009; Liow 2003). Under the security paradigm, government policies treated migrant workers as a potential threat to national security, and thus labour migration policy was formulated with the aim of controlling immigration rather than labour administration(Harkins 2016:3; Ullah 2013:183). The securitization of foreign labour management and the criminalization of undocumented migrants is evidenced from the fact that its management was moved from the Ministry of Human Resources (МонR) to the монA (Abella and Martin 2016: 92). In 2005, a One Stop Centre (OSC) was established at the монА for managing the approval process for foreign worker recruitment in line with the restructuring of foreign worker management. In the same year, the Foreign Worker Management Division was also established at the мОнА; the division functioned as the secretariat to the osc. ${ }^{18}$ Under the administration of the монА, Malaysia's labour migration policies prioritized national-security concerns, focusing on reducing undocumented migration rather than managing labour migration for economic development or protecting workers' rights (Harkins 2016:10-1). The growing political rhetoric of tighter immigration control necessitates the securitization of labour migrants, under which policy migrant workers are vulnerable to securitized immigration control measures (Arifianto 2009:624-6).

Immigration control, including the detention and deportation of undocumented migrants, is governed by the national-security framework. Immigration detention serves to punish the detainees and deter them from returning to Malaysia while allowing officials to determine the legal status of undocumented migrants prior to their deportation (Nah 2015). Enforcement operations since the 1990s have been highly securitized and militarized with the involvement of various enforcement agencies. High-profile operations have been implemented to weed out existing undocumented migrants (for instance, Ops Nyah II in 1992), while others (for instance, Ops Nyah I) were implemented to prevent illegal entry at the land and sea borders (Hedman 2008:362-3). The repatriation of undocumented migrants from Malaysia on the pretext of domestic security has jeopardized the economic interests of the nation, which relies heavily on foreign workers (Nesadurai 2013:93). Malaysia's reliance on foreign workers is demonstrated through the enforcement operation Ops Tegas,

18 Kementerian Dalam Negeri, 'Penubuhan Pusat Kelulusan Setempat (osc), Pengurusan Pengambilan Pekerja Asing'. https://www.moha.gov.my/index.php/ms/maklumat-perkhi dmatan/pengenalan-pa (accessed 18-5-2021). 
launched in 2005. This nationwide crackdown brought the economy to a standstill when 350,00o undocumented migrants were voluntarily repatriated and 400,000 undocumented migrants went into hiding. As a result of pressure from employers and severe labour shortages, the government allowed the return of repatriated Indonesian workers. Thus, ensuring an adequate labour supply for the functioning of the economy has frustrated enforcement operations in the past (Nesadurai 2013:103). Immigration enforcement measures disregard the economic fact that migrant workers form part of the Malaysian labour force and that without them many economic sectors would have to halt their operations. ${ }^{19}$

In a study conducted by the National Economic Action Council, entitled '(The) Impact of foreign workers on the Malaysian economy', which was presented by the government on 29 September 2004, the government was warned about the consequences of enforcement operations. According to the report, $46 \%$ of employers in the business sector stated that they would have to close their businesses without foreign workers, while $78 \%$ observed that the economy would be adversely affected. ${ }^{20}$ The report's warning still held true when the government launched mass arrests in 2018. Lawmakers queried whether the government had made any plans to ensure that the Malaysian economy would not be threatened as a result of the mass arrests. The country still needed these foreign workers, and an outcry from factories and industries, especially the plantation, construction, development, and agricultural sectors, followed the mass arrests. ${ }^{21}$

The tension between the labour market and immigration control is thus reflected in the frequent reversals in migrant labour policies. Policy changes and responses with respect to recruitment, employment, and enforcement have been ad hoc and reactive, often without stakeholder consultation. Malaysia's frequent migration policy shifts to reduce the population of undocumented workers have not been situated within the context of the labour market paradigm. Conflicting views over labour market needs are a result of the state's position that foreign-worker dependency is a temporary phenomenon and that the importation of foreign workers is an interim solution (Abella and Martin 2016:92-3; Anderson 2021:87).

19 Penyata rasmi Parlimen, Dewan Rakyat, 4-4-2005, p. 31. https://www.parlimen.gov.my/ files/hindex/pdf/DR-04042005.pdf (accessed 7-7-2019).

20 Penyata rasmi Parlimen, Dewan Rakyat, 4-4-2005, p. 32. https://www.parlimen.gov.my/ files/hindex/pdf/DR-04042005.pdf (accessed 7-7-2019).

21 Penyata rasmi Parlimen, Dewan Rakyat, 22-11-2018, pp. 18-19. https://www.parlimen.gov .my/files/hindex/pdf/DR-22112018.pdf (accessed 7-7-2019). 
The next section examines Malaysia's policies of legalization and amnesty. The government has initiated periodical legalization and amnesty exercises since 1989 to regulate the labour market. The high demand for migrant labour and the large number of undocumented migrants meant that the government has pushed for the migrants to register and legalize their employment status by the stipulated deadline of the legalization programmes (Kassim and Mat Zin 2011:18). The government considered the legalization initiative a practical tool which might solve almost half of the problems it faced, if not all. The government provided the undocumented migrants with documents, legalized them, and recorded them in the national database system. ${ }^{22}$ As a result, a large number of undocumented migrant workers were successfully legalized and absorbed as documented foreign workers under various programmes (Table 2).

Of all the legalization programmes, the 6P Programme (Program Penyelesaian Menyeluruh Pendatang Asing Tanpa Izin / Comprehensive Settlement Programme for Illegal Immigrants) was the largest. It was launched in 2011 to manage the growing population of undocumented migrant workers, estimated at two million, through their inclusion in a national biometric database system. The 6P Programme comprised six steps-biometric registration (pendaftaran), legalization (pemutihan), amnesty (pengampunan), monitoring (pemantauan), enforcement (penguatkuasaan), and deportation (pengusi$r a n)$. Foreign workers who registered for the programme were required to have their fingerprints taken. The introduction of biometric registration enhanced national security through the surveillance and monitoring of foreign workers, reduced human trafficking, and addressed the issue of forged identity and travel documents. ${ }^{23}$ Similarly to all the previous legalization programmes, the 6P Programme was outsourced to private companies. The Immigration Department appointed 330 companies to manage the programme. These companies charged high fees, ranging from MYR 3,OOO (USD 1,002) to MYR 4,000 per legalized worker, with an additional charge of MYR 300 to register a worker

\footnotetext{
22 Penyata rasmi Parlimen, Dewan Rakyat, 30-10-2018, p. 77. https:/www.parlimen.gov.my/ files/hindex/pdf/DR-30102018.pdf (accessed 7-7-2019).

23 Liz Gooch, 'Malaysia considers amnesty for illegal immigrants', New York Times, 7-6-2011. https://www.nytimes.com/2011/o6/o8/business/global/o8iht-amnestyo8.html (accessed 19-11-2020); 'Malaysia plans amnesty, fingerprinting', Herald Sun, 22-6-2011. https://www .heraldsun.com.au/news/breaking-news/malaysia-plans-amnesty-fingerprinting/news -story/8bo1ofebcacadaec5441744e5bbdba11 (accessed 10-8-2019).
} 
TABLE 2 Legalization, Regularization, and Amnesty Initiatives Implemented in Peninsular Malaysia $(1989-2020)$

\begin{tabular}{|c|c|c|}
\hline Initiatives & Year & Number of Irregular Migrants \\
\hline $\begin{array}{l}\text { Legalization of Indonesian workers in } \\
\text { the plantation sector }\end{array}$ & 1989 & Less than 20,000 \\
\hline Legalization Programme & 1992 & 483,784 \\
\hline Legalization Programme & 1996 & 554,941 \\
\hline Legalization Programme & 1997 & 413,813 \\
\hline Amnesty Programme & 1998 & 187,486 \\
\hline Amnesty Programme & 2002 & 439,727 \\
\hline Amnesty Programme & 2004 & $398,75^{8}$ \\
\hline Amnesty Programme & 2007 & 175,282 \\
\hline $\begin{array}{l}6 \mathrm{P} \text { (registration, legalization, amnesty, } \\
\text { monitoring, enforcement, and deporta- } \\
\text { tion). }\end{array}$ & $\begin{array}{l}1 \text { August } 2011- \\
30 \text { November } 2013\end{array}$ & $\begin{array}{l}1,303,126 \text { registered; } 503,161 \text { legalized; } \\
33 \circ, 770 \text { voluntarily repatriated }\end{array}$ \\
\hline $\begin{array}{l}\text { Special Programme for Managing Illegal } \\
\text { Immigrants (Program Khas Pengurusan } \\
\text { PATI or PKPP) }\end{array}$ & $\begin{array}{l}21 \text { October } 2013^{-} \\
20 \text { January } 2014\end{array}$ & 18,573 legalized \\
\hline $\begin{array}{l}\text { Rehiring and Relocation Programme } \\
\text { (Rehiring Programme) }\end{array}$ & $\begin{array}{l}15 \text { February } 2016- \\
31 \text { December } 2017\end{array}$ & 744,942 migrant workers registered \\
\hline Enforcement Card (e-Card) & $\begin{array}{l}15 \text { February-3o June } \\
2017\end{array}$ & $\begin{array}{l}161,056 \text { registered; only } 145,571 \text { e- } \\
\text { Cards were issued }\end{array}$ \\
\hline Three-Plus-One $(3+1)$ & $\begin{array}{l}22 \text { July 2014- } \\
30 \text { August } 2018\end{array}$ & 840,ooo voluntarily repatriated \\
\hline Back-for-Good (B4G) & $\begin{array}{l}1 \text { August 2019- } \\
31 \text { December } 2019\end{array}$ & $\begin{array}{l}\text { 195,471 registered for voluntary repatri- } \\
\text { ation }\end{array}$ \\
\hline Illegal Immigrant Recalibration Plan & $\begin{array}{l}16 \text { November } 2020- \\
30 \text { June } 2021\end{array}$ & $\begin{array}{l}200,000-250,000 \text { irregular migrants } \\
\text { targeted to take part }\end{array}$ \\
\hline
\end{tabular}

\footnotetext{
* The above statistics exclude forced-deportation programmes.
}

SOURCES: COMPILED FROM KASSIM AND MAT ZIN 2O11:18; M. KUMAR, 'FRESH BID TO SEND ILLEGAL WORKERS BACK FOR GOOD', STAR ONLINE, 19-7-2019, HTTPS://WWW.THESTAR.COM.MY/ NEWS/NATION/2O19/O7/19/FRESH-BID-TO-SEND-ILLEGAL-WORKERS-BACK-FOR-GOOD\#GMHZHWGXA UX652G6.99 (ACCESSED 10-8-2019); '165, O4O ILLEGALS REPATRIATED UNDER B4G PROGRAMME, SAYS IMMIGRATION D-G', MALAY MAIL ONLINE, 1-1-2O2O, HTTPS:/WWW.MALAYMAIL.COM/NEWS/ MALAYSIA/2O2O/O1/O1/IMMIGRATION-D-G-165O4O-ILLEGALS-REPATRIATED-UNDER-B4G-PRO GRAMME/1823883 (ACCESSED 1O-7-2O2O); PARLIAMENTARY DEBATES 16 DECEMBER 2O13:18-9; PARLIAMENTARY DEBATES 25 NOVEMBER 2014:71; PARLIAMENTARY DEBATES 22 NOVEMBER 2O18:16; GARCÉS-MASCAREÑAS 2O12:85; MAZWIN NIK ANIS, 'IMMIGRATION DEPT EXPECTS 2OO-25OK ILLEGALS TO PARTICIPATE IN LABOUR RECALIBRATION PLANS', STAR ONLINE, 4-12-2O2O, HTTPS://WWW .THESTAR.COM.MY/NEWS/NATION/2O2O/12/O4/IMMIGRATION-DEPT-EXPECTS-2OO-25OK-ILLEGALS -TO-PARTICIPATE-IN-LABOUR-RECALIBRATION-PLANS (ACCESSED 19-11-2O2O); SUN DAILY, 2-7-2O17

in the national biometric system. The companies' involvement in the 6P Programme was criticized by Malaysian NGO s as thousands of workers remained undocumented. According to the Malaysian NGO Tenaganita, more than 30,000 
workers were scammed under the 6P Programme by companies that conducted illegal activities. Many workers were not registered in the system after paying the agents. ${ }^{24}$

Since 2016, the government has eliminated outsourcing in its legalization programmes - the Rehiring and Relocation Programme (or Rehiring Programme) (2016) and the Enforcement Card Programme (2017) -in order to avoid the exploitation of immigrants. The elimination of outsourcing could be interpreted as a move to de-privatize the legalization and amnesty process and remove its commercial aspects. ${ }^{25}$ This move was significant, as the major problem encountered in all previous legalization programmes was the mishandling of the process by private agencies (Jones 2000:20). Prior to 2016, all legalization programmes under the government were outsourced to agents who were allowed to profit from the collection of registration fees. The process was complicated and costly, with the involvement of the agents in the registration process being sufficiently monitored ${ }^{26}$ Civil society groups criticized the privatization of the state's legalization programmes and called for the abolition of private-agent involvement in the legalization programmes. They argued that amnesty and legalization exercises should be conducted by the Immigration Department to 'discourage profiteering. ${ }^{27}$

Since 2019, the government has barred repatriated migrants from re-entering the country. Under the new amnesty programme, called Back for Good, the government aims to send back undocumented migrants permanently. This contrasts sharply with all previous amnesty initiatives, in which undocumented migrants were facilitated to return to Malaysia for legal employment. The past initiatives failed to achieve the objective of facilitating their return. Many of the immigrants returned to Malaysia via illegal routes instead. ${ }^{28}$ The ultimate

24 Irène Fernandez, 'In Malaysia, the scandal of outsourcing companies is at the heart of forced labour', Human Resources Without Borders, 1-4-2014. http://www.rhsansfrontieres .org/en/press/our-press-opinion/329-article-malaysia-forced-labour (accessed 1o-8-2019); Eileen Ng, 'Activists fear abuse in Malaysian labor amnesty', Irrawaddy, 29-7-2011. https:// www2.irrawaddy.com/article.php?art_id=21793 (accessed 19-11-2020).

25 'Govt ends MyEG's rehiring programme', Sun Daily, 3-7-2018. https://www.thesundaily .my/archive/govt-ends-myegs-rehiring-programme-JUARCH552369 (accessed 10-7-2020); 'Employers want more time for E-Card registration', Star Online, 3o-6-2017. https://www .thestar.com.my/news/nation/2017/o6/30/employers-want-more-time-for-ecard -registration\#za42QGSWUYWzf6MC.99 (accessed 10-8-2019).

26 Penyata rasmi Parlimen, Dewan Rakyat, 30-10-2018, p. 74. https://www.parlimen.gov.my/ files/hindex/pdf/DR-30102018.pdf (accessed 7-7-2019).

27 Civil Society Organisations, 'Immigration raids make criminals out of victims', Malaysiakini, 4-7-2018. https://www.malaysiakini.com/letters/432752 (accessed 10-8-2019).

28 Penyata rasmi Parlimen, Dewan Rakyat, 22-6-2005, pp. 80-2. https://www.parlimen.gov .my/files/hindex/pdf/DR-22062005.pdf (accessed 7-7-2019). 
objective of the Back for Good programme is to ensure that the migrants do not return to Malaysia. Permanent repatriation also signals an increased penalty for surrendering migrants, who are barred from re-entering Malaysia for an indefinite period. ${ }^{29}$

\section{Replacing Outsourced Agents with Government-Appointed Immigration Contractors}

The Malaysian government changed its policy towards legalization programmes in 2016. The state ceased to outsource the process of legalization to private agents, replacing them with immigration contractors during the implementation of the Rehiring Programme (2016) and the Enforcement Card Programme (2017). The Immigration Department appointed three private companies as official immigration contractors to undertake the Rehiring Programme: International Marketing and Net Resources Sdn Bhd for Indonesian nationals; Bukti Megah Sdn Bhd for Myanmar nationals; and Konsortium PMF (including MyEG Sdn Bhd) for other nationalities. The vendors compiled the documents required for registration with employers. ${ }^{30}$ The монА estimated that there were two million undocumented foreign workers when it launched the Rehiring Programme in February 2016. Employers were allowed to register their workers online, without the use of an agent. The мона recognized that intermediaries' involvement would allow them to make a profit from the employers by charging registration fees. In addition, in many cases, these agents had failed to register the workers and this had resulted in workers overstaying their permits. Online registration would help the employers to avoid penalties once they had completed their workers' registration. ${ }^{31}$

The Rehiring Programme was implemented to meet the labour demand in various sectors while reducing the number of undocumented workers. Strict qualification requirements were imposed on foreign workers: they had to have entered the country legally, be employed, and not have a criminal record. Employers were charged registration fees (MYR 800 or USD 178) and admin-

\footnotetext{
29 Cindi Loo, 'Back-for-Good amnesty programme for overstaying foreigners', Sun Daily, 187-2019. https://www.thesundaily.my/local/back-for-good-amnesty-programme-for -overstaying-foreigners-DD1126849 (accessed 10-8-2019).

30 'Govt ends MyEG's rehiring programme', Sun Daily, 3-7-2018. https://www.thesundaily.my/ archive/govt-ends-myegs-rehiring-programme-JUARCH552369 (accessed 10-7-2020).

31 'Malaysia to rehire $2 \mathrm{~m}$ illegal workers', Straits Times, 6-2-2016. https://www.straitstimes .com/asia/se-asia/malaysia-to-rehire-2m-illegal-workers (accessed 10-8-2019).
} 
istrative charges (MYR 400 or USD 89) imposed by the selected immigration vendors. The Immigration Department imposed other charges separately on the employers for the levy, visa, processing fee, work permits, and fines for immigration offences, totalling between MYR 1,395 and MYR 3,485 to legalize each worker. $^{32}$

The outsourcing of the process to the three official vendors was protested by the employers, who regarded the task as the responsibility of the Immigration Department. Some industry players complained that the process was lengthy, tedious, and involved red tape under these vendors, leaving employers uncertain about the status of the registration. Employers urged the government to eliminate the use of intermediaries and simplify the process. Many employers preferred to deal directly with the Immigration Department to register their experienced workers. ${ }^{33}$ Despite employers' complaints of the registration fees imposed, Deputy Home Minister Nur Jazlan Mohamed stated that there would be no reduction since 'the rate is a fair trade-off' taking into consideration the detention and deportation costs after the workers' permits had expired. The online registration process was simple for the employers, not requiring them to attend the Immigration Office or use an agent. ${ }^{34}$

The Rehiring exercise failed to achieve the objective of eliminating intermediaries. Despite the Immigration Department's announcement that no agents were involved in the Rehiring Programme, there were numerous cases of fraud syndicates operating the programme illegally. Illegal agents, and in some cases government-outsourced contractors, defrauded foreign workers. It should be noted that only the three authorized immigration contractors and some of their subsidiary companies were allowed to manage the Rehiring Programme. The problem of syndicates accessing the Rehiring Programme had grown when some of the subsidiaries of authorized contractors abused their approval and processed foreign workers' applications with false documents. Some subsidiary companies even partnered with foreign workers in defrauding undocumented migrants. ${ }^{35}$ The rehiring process was not transparent under the administra-

32 Iwan Shu-Aswad Shuaib, 'Rehiring costs RM1,200', Star Online, 15-12-2016. https://www .thestar.com.my/news/nation/2016/o2/15/rehiring-costs-rm120o/ (accessed 10-7-2020).

33 Rahimy Rahim, 'Chance to legalise illegal workers', Star Online, 25-1-2017. https://www .thestar.com.my/news/nation/2017/o1/25/chance-to-legalise-illegal-workers-employers -can-apply-for-immigration-departments-ekad-starting-feb\#LF2qtB3ouTMrSM7M.99 (accessed 10-8-2019).

34 Mazwin Nik Anis, 'No reduction in registration fee under Rehiring Programme', Star Online, 2-3-2016. https://www.thestar.com.my/news/nation/2016/o3/o2/no-reduction-in -registration-fee-under-rehiring-programme/ (accessed 10-7-2020).

Teoh Pei Ying, 'Immigration Dept busts Rehiring Programme syndicate', New Straits Times, 
tion of the government-outsourced vendors as the process involved brokers and sub-agents. ${ }^{36}$ There were foreign workers, who after having paid the government-appointed vendors, were not being issued work permits. In the cases handled by Tenaganita, workers applying for the Rehiring Programme paid MYR 6,ooo to the vendors, but not all of them were successfully rehired. The vendors attributed the failure to process their applications on time to the government, while the government refused to take responsibility, resulting in half a million workers losing their money and becoming 'victims' of the registration exercise. The privatization of the Rehiring Programme was described by Tenaganita as generating revenue for the 'crony vendors'. ${ }^{37}$

In addition to mishandling by the government-outsourced vendors (and their subsidiaries companies), there were also cases of foreign workers being defrauded by illegal agents. A local news source reported that a counterfeit syndicate profited to the tune of MYR 2.2 million by promising valid work permits to undocumented migrants even after the programme deadline. The migrants paid MYR 8,00o each to the syndicate to secure an employment permit. ${ }^{38}$ There were also reported cases of foreign-operated syndicates accessing the Rehiring Programme illegally. The Immigration Department raided a syndicate owned by a Bangladeshi, who had accessed the programme illegally for more than a year, charging undocumented migrants between MYR 5,500 and MYR 8,000 each for registration. The Immigration Department cautioned employers and foreign workers that they should contact the department directly for advisory services, and not use any mediators. ${ }^{39}$

The Rehiring Programme aimed to provide undocumented migrant workers with valid work permits to meet the demands of the authorized employment sectors. Employers and migrant workers were given a grace period of one year and ten months ( 15 February 2016-31 December 2017) to register their foreign

11-7-2018. https://www.nst.com.my/news/nation/2018/o7/389774/immigration-dept-busts -rehiring-programme-syndicate (accessed 10-7-2020).

36 'Stop using migrants as ATM s, Tenaganita tells govt', Malaysiakini, 19-7-2019. https://www .malaysiakini.com/news/484542 (accessed 10-8-2019).

37 Minderjeet Kaur, 'Tenaganita says 500,000 migrant workers cheated in "govt-sponsored scam"', Free Malaysia Today, 17-12-2019. https://www.freemalaysiatoday.com/category/ nation/2019/12/17/tenaganita-says-50oooo-migrant-workers-cheated-in-govt-sponsored -scam/ (accessed 10-7-2020).

38 'Immigration Dept busts fake rehiring group', Star Online, 15-8-2018. https://www.thestar .com.my/news/nation/2018/o8/15/cops-bust-fake-rehiring-group-syndicate-had-cheated -over-270-foreign-workers-from-four-countries (accessed 10-7-2020).

39 'Immigration Dept nab Bangladeshi for operating re-hiring programme illegally', Sun Daily, 6-7-2018. http://www.thesundaily.my/news/2018/o7/o6/immigration-dept-nab -bangladeshi-operating-re-hiringprogramme-illegally (accessed 10-8-2019). 
workers. The government extended the screening process until $30 \mathrm{June} 2018$ for those who had registered. During the programme, 83,919 employers and 744,942 migrant workers registered, far below the Immigration Department's initial target. ${ }^{40}$ Out of the 744,942 registered workers, 307,557 qualified for the programme, subject to health-screening results. Around 108,234 applications were rejected on various grounds and 329,151 applications were pending because the workers had not yet provided their biometric information or undergone healthscreening processes. Registered workers who did not qualify for the Rehiring Programme were repatriated under the Three Plus One amnesty programme by employers and vendors. ${ }^{41}$ Errant employers who failed to legalize or repatriate their workers after the 30 June 2018 deadline were subject to legal action. The Immigration Department launched a nationwide enforcement operation called Ops Mega 3.0 on 1 July 2018 to 'flush out' undocumented migrants and arrest errant employers. Employers are liable to a maximum fine of MYR 5O,OOO, imprisonment for five years, and/or six strokes with a whip under the Immigration Act 1959/1963. ${ }^{42}$

A noticeable trend among Malaysian employers is the registration of workers at the last minute. Many employers were delaying registration in order to delay the payment of foreign-worker levies. The монA announced that 30 June would be the final deadline for the Rehiring Programme, by which date employers must have completed the registration process and made payment. ${ }^{43}$ At the beginning of the Rehiring Programme, no employer came forward to register their workers. Though the employers had had sufficient time, they only flocked to register their workers towards the end of the programme. ${ }^{44}$ Many employers had a 'nonchalant' or 'wait-and-see attitude' to registering and obtaining valid work permits for their workers. Deputy Home Minister Nur Jazlan Mohamed reminded employers not to wait until the last minute as fines would be imposed

40 Penyata rasmi Parlimen, Dewan Rakyat, 22-11-2018, p. 16. https://www.parlimen.gov.my/ files/hindex/pdf/DR-22112018.pdf (accessed 7-7-2019).

41 'No more second chances for illegal immigrants and their bosses come July 1', New Straits Times, 1-6-2018. https://www.nst.com.my/news/nation/2018/o6/375479/no-more-second -chances-illegal-immigrants-and-their-bosses-come-july-1 (accessed 10-8-2019).

42 'New operation to flush out illegal immigrants on July 1', Star Online, 2-6-2018. https://www .thestar.com.my/news/nation/2018/o6/o2/new-operation-to-flush-out-illegal -immigrants-on-july-1/ (accessed 1o-8-2019); 'Govt ends MyEG's rehiring programme', Sun Daily, 3-6-2018. https://www.thesundaily.my/archive/govt-ends-myegs-rehiring -programme-JUARCH552369 (accessed 10-8-2019).

43 'Govt ends MyEG's rehiring programme', Sun Daily, 3-6-2018. https://www.thesundaily.my/ archive/govt-ends-myegs-rehiring-programme-JUARCH552369 (accessed 1o-8-2019).

44 Penyata rasmi Parlimen, Dewan Rakyat, 22-11-2018, p. 18. https://www.parlimen.gov.my/ files/hindex/pdf/DR-22112018.pdf (accessed 7-7-2019). 
for hiring undocumented workers after the deadline. Nur Jazlan attributed the influx of undocumented migrants in the country to the employers' attitude: 'They (employers) want foreign workers but did not want to be responsible for them. 45

Another legalization programme, called the Enforcement Card (E-Card) Programme, was launched in 2017; it aimed to address the labour shortages in five sectors - plantation, agriculture, industrial, construction, and servicesin Peninsular Malaysia. The e-Card functioned as a temporary document, which had to be replaced by valid travel documents from the workers' respective embassies. The e-Card legalization programme only allowed registered workers to be hired for one year, after which they had to have a work permit to continue working. The programme allowed employers to rehire their currently employed workers legally and was open to applications between 15 February and 30 June 2017. To avoid exploitation by agents, the Immigration Department processed the applications and issued the e-Cards for free, without any intermediaries. Foreign workers had to comply with strict regulations to qualify: they had to be employed, come from an approved source country, have no criminal record, pass the health tests, and not have absconded from any employment. ${ }^{46}$

Even though the e-Cards were issued directly by the Immigration Department, it outsourced the subsequent process of rehiring to three immigration contractors, instead of agents. International Marketing and Net Resources Sdn Bhd managed illegal immigrants from Indonesia; Bukti Megah Sdn Bhd handled those from Myanmar; and Konsortium PMF dealt with immigrants from other countries. The e-Cards expired on 15 February 2018, when undocumented immigrants and their employers had to submit valid passports for the rehiring process. Those who did not qualify for legalization were also repatriated through the three appointed companies. ${ }^{47}$

45 'Immediately register illegal immigrants via Rehiring Programme', Sun Daily, 24-2-2016. https://www.thesundaily.my/archive/1708636-YSARCH351603 (accessed 10-8-2019).

46 Rahimy Rahim, 'Chance to legalise illegal workers', Star Online, 25-1-2017. https://www .thestar.com.my/news/nation/2017/o1/25/chance-to-legalise-illegal-workers-employers -can-apply-for-immigration-departments-ekad-starting-feb\#LF2qtB3ouTMrSM7M.99 (accessed 10-8-2019); 'Employers want more time for E-Card registration', Star Online, 3o-62017. https://www.thestar.com.my/news/nation/2017/06/30/employers-want-more-time -for-ecard-registration\#za42QGSWUYWzf6MC.99 (accessed 10-8-2019).

47 'Immigration department appoints three companies to assist in rehiring programme-DG', New Straits Times, 15-12-2018. https://www.nst.com.my/news/nation/2018/o2/335942/ immigration-department-appoints-three-companies-assist-rehiring-programme (accessed 10-8-2019). 
The immigration contractors were regarded by MP Steven Sim as 'papershifters', operating within the flawed labour migration system. Despite the Immigration Department's statement that no intermediaries would be engaged in processing the e-Card application and that the e-Card would be free for workers, employers were required to go through the three immigration contractors to apply for the free e-Card and paid MYR 800 for registering each worker. Steven Sim regarded the contractors' involvement in the E-Card Programme as a redundant extra layer of bureaucracy. Based on the targeted registration of 60o,ooo migrant workers, the three immigration contractors were expected to make MYR 500 million in profit from paper-shifting when, in actual fact, the authorization was being granted by the government. The Immigration Department was called to manage foreign workers' registrations directly. ${ }^{48}$ Eliminating the agents' involvement prevented the fabrication of eCards. Raids conducted by the Immigration Department detected fraudulent agents who had falsified e-Cards and attempted to issue them. Between 15 February and 5 July 2017 , the department detected 40 false e-Cards and took legal action against such agents. ${ }^{49}$

The Immigration Department failed to achieve its target of registering 400,000 to 600,00o foreign workers through the E-Card Programme, with only 161,056 illegal foreign workers registered and only 145,571 e-Cards issued. The failure was mainly due to many employers' refusal to register their workers in time. Thus, many had not been registered when the deadline passed. These employers' stubbornness to register and respond to the programme, despite being given the opportunity, resulted in the government not extending the deadline. ${ }^{50}$ During the programme, employers, represented by the Malaysian Employers Federation (MEF), urged the government to extend the registration deadline, broaden the eligibility, and loosen the stringent conditions. Many employers swarmed to the immigration office on the day of the deadline. The Immigration Department refused any extension, citing that ample time had been given, and started enforcement operations. ${ }^{51}$ Employers had taken the

48 'DAP: Agents make millions for "paper-shifting” at immigration', Free Malaysia Today, 22-32017. https://www.freemalaysiatoday.com/category/nation/2017/o3/22/dap-agents-make -millions-for-paper-shifting-at-immigration/ (accessed 10-7-2020).

'Immigration Department detects false E-Cards', New Straits Times, 5-7-2017. https://www .nst.com.my/news/nation/2017/o7/254655/immigration-department-detects-false-e -cards (accessed 10-8-2019).

'Immigration begins massive ops to flush out illegals', Sun Daily, 2-7-2017. https://www .thesundaily.my/archive/immigration-begins-massive-ops-flush-out-illegals-FTARCH457 476 (accessed 10-8-2019).

'Employers want more time for E-Card registration', Star Online, 3o-6-2017. https://www 
amnesty programme for granted. Errant employers disregarded the law and complained of labour shortages when enforcement operations were carried out. The Immigration Department considers employers harbouring undocumented migrants to be the culprits behind the long-standing problem of undocumented foreign workers in Malaysia. ${ }^{52}$

The director-general of the Immigration Department, Mustafar Ali, was disappointed at the 'last-minute culture' among Malaysian employers. Some employers had taken it for granted that there would be another extension and delayed the registration of their workers. When the government announced that there would be absolutely no extension of the E-Card Programme deadline, these employers then rushed to immigration offices during the last few days of the programme. Mustafar Ali blamed the lackadaisical attitude of the employers for the low response rate. Only 145,571 e-Cards were issued when the department had targeted the registration of between 400,000 and 600,000 e-Cards. ${ }^{53}$ After the deadline, undocumented or unregistered workers were arrested, detained, and deported under a nationwide crackdown. Many undocumented workers were not registered because their employers had not applied for an e-Card for them, and they themselves were unaware of the programme. According to Mustafar Ali, employers were to be held responsible for the failure of the programme in registering the estimated 6oo,ooo undocumented workers. The E-Card Programme was unsuccessful because irresponsible employers failed to register their workers, and this was most likely caused by their anticipation that the deadline would be extended. In a nationwide crackdown, irresponsible employers who had ignored the validity of their workers' work permits were targeted by the Immigration Department. The employers were charged under the Immigration Act 1959/1963 and the Anti-Money Laundering, Anti-Terrorism Financing and Proceeds of Unlawful Activities Act 2001. The second Act allowed the government to freeze these companies' assets for investigations. ${ }^{54}$

.thestar.com.my/news/nation/2017/06/3o/employers-want-more-time-for-ecard-registra tion\#za42QGSWUYWzf6MC.99 (accessed 10-8-2019).

52 'Employers to blame for illegal foreign workers issue: Immigration DG', Sun Daily, 6-8-2017. https://www.thesundaily.my/archive/employers-blame-illegal-foreign-workers-issue -immigration-dg-XTARCH468086 (accessed 10-8-2019).

'Fuming Immigration boss: Deadline for E-Card registration stays', Star Online, 1-7-2017. https://www.thestar.com.my/news/nation/2017/o7/o1/absolutely-no-extension-fuming -immigration-boss-deadline-for-ecard-registration-stays/ (accessed 10-8-2019).

54 Jasmine Andria and Christopher Rabin, 'Irresponsible employers must be held accountable', Malay Mail Online, 2-7-2017. https:/www.malaymail.com/news/malaysia/2017/o7/ o2/irresponsible-employers-must-be-held-accountable/1411657 (accessed 10-7-2020). 
While the E-Card Programme assisted with monitoring and enforcement, there was the question of whether it would be a viable solution to the heavy influx of foreign workers. For the Malaysian Trades Union Congress (MTUC), the legalization programme created an incorrect perception of foreign workers. Malaysia was viewed as a country that allowed undocumented migrants to obtain work permits without being detained and deported while accepting and legalizing those who had illegally crossed the border, thereby breaking the law and threatening the country's sovereignty. There were concerns about the negative consequences of this programme, because the origins of those without valid documents could not be ascertained. ${ }^{55}$ Recognizing undocumented migrants and errant employers through amnesty exercises discriminates against those who follow the rule of law. Indeed, the law imposes severe penalties on errant employers who hire workers illegally, but the situation in Malaysia does not encourage employers to legally hire foreign workers. Those complying with the law pay thousands of ringgit to hire a foreign worker legally, whereas those who do not follow the legal procedure can pay a higher salary and incur lower production costs. Those violating the law are granted amnesty under a variety of programmes. Thus, the implementation of amnesty and legalization programmes has created a situation where law-abiding employers become victims. It is important to ensure that those complying with the law, rather than those who violate the law, are rewarded and not victimized. ${ }^{56}$

A noticeable trend in legalization exercises is the gradual move towards semi-legalization, and, what is more, legalization that meets stringent conditions and has higher costs for employers. Neither the Rehiring Programme nor the E-Card Programme was a fully fledged legalization programme compared to the previous 6P Programme. The 6P Programme allowed any undocumented workers to register, and registration could be completed directly with the Immigration Department for free or through an agent at a cost of MYR 30. However, the Rehiring Programme required employers to work through the appointed immigration contractors with registration and administration fees of MYR 1,200. For construction companies, the rehiring process cost about MYR 3,000, which included vendor charges, immigration charges and insurance, and a levy of MYR 1,850. According to the Master Builders Association of Malaysia, the cost of legalizing existing workers was higher than the cost of hiring new foreign workers in the construction sector. The strict conditions and

55 'Will the E-Card for illegals help?', Astro Awani, 30-1-2017. http://english.astroawani.com/ malaysia-news/will-e-card-illegals-help-130682 (accessed 10-8-2019).

56 Penyata rasmi Parlimen, Dewan Rakyat, 20-3-2017, p. 31. https://www.parlimen.gov.my/ files/hindex/pdf/DR-20032017.pdf (accessed 7-7-2019). 
the exorbitant fees imposed drew negative responses from the foreign workers and led to labour shortages in the construction industry, causing delays in the completion of construction works and affecting the construction companies' revenues. ${ }^{57}$ At the end of the Rehiring Programme, industry players requested that the government have a 'final round' of rehiring. They wanted one more proper Rehiring Programme because the existing one was deemed complicated and costly and involved multi-layered processes and employers having to deal with three vendors. ${ }^{58}$

Given the high costs, it is not surprising that the employers preferred the old 6P Programme to the Rehiring Programme. In July 2018, 109 industry associations and chambers jointly submitted a proposal to the ministers of home affairs and human resources, calling for an extension of the Rehiring Programme for six months based on the 6P Programme conditions. Employers complained about the disruption in production due to the delayed approval of applications, which was caused by third-party agents. The Rehiring Programme was open to abuse. The industry players demanded that the process be handled solely by the Immigration Department, without third-party agents or service providers. Many employers were against the blacklisting of employers and the freezing of new worker intake during the process. ${ }^{59}$

Similarly, the E-Card Programme was not a fully fledged legalization programme. It was more like a registration process that offered workers a temporary identification card (for those without valid documents), allowed the Immigration Department to collect data on undocumented foreign workers, and allowed employers to avoid legal action. After registration ended, the eCard holders needed to produce their passports and secure work permits by February 2018. Employers had to register their workers, as those who were not employed were not eligible to participate in the programme. The MEF described the E-Card Programme as a 'tricky' option, which did not benefit employers. It was introduced for surveillance purposes to collect biometric

57 'Days of "cheap" foreign labour over for builders', Sun Daily, 30-7-2017. https://www.thesun daily.my/archive/days-cheap-foreign-labour-over-builders-FTARCH465985 (accessed 107-2020).

$5^{8}$ Aliza Shah and Teh Athira Yusof, 'Industry urges "final round" of rehiring programme', New Straits Times, 6-8-2018. https://www.nst.com.my/news/exclusive/2018/08/398458/indus try-urges-final-round-rehiring-programme (accessed 10-7-2020).

59 Federation of Malaysian Manufacturers, 'FMM press statement: Suspend on-going raids and further 6-month extension of foreign worker rehiring programme \& review of minimum wages rate to take effect from 2019', 13-7-2018. https://www.fmm.org.my/sub_page .aspx?id=ed4911c5-1bao-488e-bd5e-o37c1d6d2b2e\&pid=af3e24ac-fe14-4421-9986-15dbod3 od988\&print $=1$ (accessed 10-8-2019). 
data on undocumented workers. The employers wanted the implementation of full legalization, combined with the elimination of agents, as a long-term solution. ${ }^{60}$

\section{$5 \quad$ Replacing Lenient Repatriation with Permanent Repatriation}

A totally different approach to managing undocumented migration is to repatriate migrants to their home country. Voluntary repatriation (also known as amnesty) is implemented simultaneously with legalization programmes. Foreign workers who were not eligible under the Rehiring and E-Cards Programmes were repatriated under the Three Plus One (3-plus-1) amnesty programme. The Immigration Department launched the Three Plus One programme in 2014 to allow undocumented migrants to return home without being subject to legal action including imprisonment and fines. Errant employers who failed to surrender their undocumented workers for repatriation were also subject to enforcement operations after the deadline of legalization programmes had passed. ${ }^{61}$ Participants in the Three Plus One programme were barred from entering the country for a five-year period after having their biometric records taken. Under the 3-plus-1 programme, the participants were fined MYR 300 and forced to pay a special pass fee of MYR 100 (hence the name of the programme) and were exempted from prosecution for related offences under the Immigration Act 1959/1963. ${ }^{62}$ Two immigration offences were pardonable: irregular entry into the country without a valid passport and permit, and overstaying or use of a tourist visa to enter the country. The programme was used to send back migrant workers, whether they were arrested or surrendered voluntarily (Table 3). ${ }^{63}$

6o Kong See Hoh, 'E-Card a "tricky" option, says MEF', Sun Daily, 15-2-2017. https://www .thesundaily.my/news/2163193 (accessed 10-7-2020).

61 Ooi Tee Ching, 'Employers told to surrender illegal foreign workers under 3-plus-1 programme', New Straits Times, 6-7-2017. https://www.nst.com.my/news/nation/2017/07/2549 86/employers-told-surrender-illegal-foreign-workers-under-3-plus-1-programme (accessed 19-11-2020); 'Employers want more time for E-Card registration', Star Online, 306-2017. https://www.thestar.com.my/news/nation/2017/06/30/employers-want-more -time-for-ecard-registration\#za42QGSWUYWzf6MC.99 (accessed 10-8-2019).

62 Penyata rasmi Parlimen, Dewan Rakyat, 22-11-2018, p. 17. https://www.parlimen.gov.my/ files/hindex/pdf/DR-22112018.pdf (accessed 7-7-2019).

63 Penyata rasmi Parlimen, Dewan Negara, 28-4-2016, p. 5. https://www.parlimen.gov.my/ files/hindex/pdf/DN-28042016.pdf (accessed 7-7-2019). 
TABLE 3 Three-plus-one voluntary repatriation programme, 22 July 2014-27 May 2018

\begin{tabular}{|c|c|c|c|c|c|c|c|}
\hline No. & Nationality & 2014 & 2015 & 2016 & 2017 & 2018 & Total \\
\hline 1 & Indonesia & 47,235 & 75,932 & 91,093 & 107,374 & $5^{6,151}$ & 377,785 \\
\hline 2 & Nepal & 20,778 & 23,377 & 12,371 & 17,218 & 6,083 & 79,827 \\
\hline 3 & Bangladesh & 11,184 & 13,266 & 20,188 & 37,024 & 8,225 & 89,887 \\
\hline 4 & India & 11,183 & 14,357 & 13,501 & 20,691 & 9,133 & 68,865 \\
\hline 5 & Myanmar & 2,832 & 13,538 & $15,35^{\circ}$ & 16,683 & 3,951 & $5^{2,354}$ \\
\hline 6 & Pakistan & 8,721 & 10,347 & 7,594 & 7,324 & 1,991 & 35,977 \\
\hline 7 & Vietnam & 2,220 & 8,229 & 6,926 & 3,197 & 629 & 21,201 \\
\hline 8 & Sri Lanka & 3,287 & 3,421 & 2,535 & 2,109 & 657 & 12,009 \\
\hline 9 & Philippines & $1,1 \circ 6$ & 2,416 & 3,208 & 3,555 & 963 & 11,248 \\
\hline 10 & Cambodia & 388 & 2,586 & 2,564 & 2,143 & 656 & 8337 \\
\hline 11 & China & 534 & 1,119 & 2,690 & 4,790 & 3,287 & 12420 \\
\hline 12 & Nigeria & 557 & 559 & 627 & 1,242 & 641 & 3626 \\
\hline 13 & Syria & 64 & 175 & 70 & 178 & 73 & 560 \\
\hline 14 & Iran & 64 & 136 & 80 & 79 & 57 & 416 \\
\hline 15 & Thailand & 99 & 71 & 116 & 422 & 46 & 754 \\
\hline 16 & Others & 2,024 & 1,262 & 1,315 & 2,090 & 774 & 7,465 \\
\hline Total & & 112,276 & 170,791 & 180,228 & 226,119 & 93,317 & 782,731 \\
\hline
\end{tabular}

* A total of 840,00o irregular migrants participated in the three-plus-one programme, which ended on 30 August 2018. The above figure for 2018 only captured the numbers up to 27 May 2018.

SOURCE: KEMENTERIAN DALAM NEGERI, 'PROGRAM (PATI SERAH DIRI) MENGIKUT WARGANEGARA DARI TAHUN 2014 HINGGA 27 MEI 2018'. HTTPS://WWW.DATA.GOV.MY/DATA/ EN_US/DATASET/PROGRAM-PATI-SERAH-DIRI-MENGIKUT-WARGANEGARA/RESOURCE/ 9O1D433D-4457-44A3-BDB5-FF7984D3B17O (ACCESSED 16-12-2O2O).

The government considered the four-year programme (22 July 201430 August 2018) effective, as 840 ,ooo illegal immigrants were repatriated and MYR 400 million in fines was collected. ${ }^{64}$ The voluntary return programme allowed the state to expedite deportation cases without having to go through

64 M. Kumar, 'Fresh bid to send illegal workers back for good', Star Online, 19-7-2019. https:// www.thestar.com.my/news/nation/2019/o7/19/fresh-bid-to-send-illegal-workers-back -for-good\#gMhZhwGXAuX652g6.99 (accessed 10-8-2019); 'Hampir 50,00o PATI ditahan sejak Januari-Nur Jazlan', Astro Awani, 19-12-2016. https://www.astroawani.com/berita -malaysia/hampir-50ooo-pati-ditahan-sejak-januari-nur-jazlan-126165 (accessed 18-5-20 21). 
the process of detention and court hearings for offenders, who would otherwise be charged with immigration violations. It alleviated backlogs in the detention centres while reducing the state's expenses, since the deportees paid for their own flights. ${ }^{65}$ Compared to the normal deportation process, which is costly and lengthy due to difficulties in determining citizenship status with respective embassies, the process of sending back those who surrendered voluntarily was much easier. The Three Plus One programme was in line with the Immigration Department's aspiration to completely free the country of undocumented migrants by 2020. In 2014, the department had pledged to bring down the number of undocumented migrants to zero. ${ }^{66}$ The date 31 August, the nation's Independence Day, marked the end of the programme and the department stepped up its enforcement efforts. In conjunction with the celebrations for the national independence day, the director-general of the Immigration Department reiterated his pledge to liberate the country of undocumented migrants. ${ }^{67}$

In July 2019, the монА announced a new amnesty programme called Back for Good $\left(\mathrm{B}_{4} \mathrm{G}\right)$ to reduce the number of undocumented migrants and to reduce the cost of immigration detention center management. Under $\mathrm{B}_{4} \mathrm{G}$ (1 August 2019-31 December 2019), undocumented migrants were given the chance to surrender voluntarily. A significant feature of the $B 4 G$ programme is that it permanently repatriates the undocumented migrants participating in the programme. Permanent repatriation has replaced the previous lenient amnesty regime, which allowed repatriated migrants to re-enter Malaysia legally. Instead of blacklisting the repatriated migrants for five years (as implemented under the Three-Plus-One programme), the government sought to repatriate them permanently and they were blacklisted for an indefinite period. ${ }^{68}$ Despite the мона announcement that there would be no more amnesty programmes after Three-Plus-One, the government reluctantly

65 Penyata rasmi Parlimen, Dewan Rakyat, 25-11-2014, p. 98. http://www.parlimen.gov.my/ files/hindex/pdf/DR-25112014.pdf (accessed 7-7-2019).

66 'Immigration Department promises no more illegal immigrants by 2020', Malaysian Insider, 4-12-2014. http://www.themalaysianinsider.com/malaysia/article/immigration -department-promises-no-more-illegal-immigrants-by-202o-bernama\#sthash.Si6deiM 8.dpuf (accessed 10-8-2019).

67 Aliza Shah, 'No deadline set for Op Mega 3.o', New Straits Times, 29-7-2018. https://www .nst.com.my/news/nation/2018/07/395567/no-deadline-set-op-mega-3o (accessed 10-82019).

68 Cindi Loo, 'Back-for-Good amnesty programme for overstaying foreigners', Sun Daily, 187-2019. https://www.thesundaily.my/local/back-for-good-amnesty-programme-for -overstaying-foreigners-DD1126849 (accessed 10-8-2019); 'Over 180,ooo repatriated under Back for Good amnesty programme', Malaysiakini, 31-12-2019. https://www.malaysiakini .com/news/50549o (accessed 10-7-2020). 
launched $\mathrm{B}_{4} \mathrm{G}$. The minister of home affairs, Muhyiddin Yassin, sent out the strong message of 'Don't come back' and stated that those who were repatriated would be blacklisted. The government hoped that repatriated migrants would not return and this became clear from the fact that it would not settle any salary disputes between undocumented foreign workers and their employers. ${ }^{69}$

The Immigration Department aimed to repatriate around 300,000-400,000 migrants. The participants were required to approach their respective embassies for valid travel documents. A fine of MYR 700 was imposed on participants for this voluntary return. Similar to past programmes, B4G applied to overstaying foreigners under section 15(1)(c) of Immigration Act 1959/1963, and to those without valid travel documents under section 6(1)(c). ${ }^{70}$ The new immigration director-general, Khairul Dzaimee Daud, described the implementation of the programme as a major achievement in cracking down on undocumented migrants. A total of 195,471 immigrants registered under the $\mathrm{B}_{4} \mathrm{G}$ amnesty exercise before the deadline. As of 1 January $2020,165,040$ immigrants had been repatriated while the remaining 30,431 were waiting for their flight. ${ }^{71}$

Another significant feature of $\mathrm{B} 4 \mathrm{G}$ was the elimination of any third-party involvement by the Immigration Department. Undocumented migrants dealt directly with the department to obtain exit documents and pay the fine. Upon approval by the Immigration Department, they had to leave the country within one week. The amnesty programme offered the undocumented migrants the opportunity to return home safely without paying for the dubious services of syndicates. In previous amnesty exercises, many overstaying migrants had used syndicates that offered fake entry and exit stamps instead of using the proper channels. ${ }^{72}$ However, the goal of excluding agents was not achieved. During the

69 M. Kumar, 'Fresh bid to send illegal workers back for good', Star Online, 19-7-2019. https:// www.thestar.com.my/news/nation/2019/o7/19/fresh-bid-to-send-illegal-workers-back -for-good\#gMhZhwGXAuX652g6.99 (accessed 10-8-2019).

70 Cindi Loo, 'Back-for-Good amnesty programme for overstaying foreigners', Sun Daily, 187-2019. https://www.thesundaily.my/local/back-for-good-amnesty-programme -for-overstaying-foreigners-DD1126849 (accessed 10-8-2019).

71 'Over 180,ooo repatriated under "Back for Good” amnesty programme', Malaysiakini, 3112-2019. https://www.malaysiakini.com/news/50549o (accessed 10-7-2020); '165,040 illegals repatriated under $\mathrm{B} 4 \mathrm{G}$ programme, says Immigration D-G', Malay Mail Online, 11-2020. https://www.malaymail.com/news/malaysia/2020/o1/o1/immigration-d-g-165040 -illegals-repatriated-under-b4g-programme/1823883 (accessed 10-7-2020).

72 Mazwin Nik Anis, 'Illegal immigrants should use legal channel to return home', Star Online, 20-7-2019. https://www.thestar.com.my/news/nation/2019/o7/20/illegal-immigrants -should-use-legal-channelto-return-home\#Th3JkdxPcbcrPMhi.99 (accessed 10-8-2019). 
implementation of $\mathrm{B}_{4} \mathrm{G}$, the department received complaints about the existence of illegal agents at the immigration offices in Putrajaya and Kuala Lumpur, which were offering their services to speed up the registration process. ${ }^{73}$ Though it was announced by the department that no agents would be engaged in $\mathrm{B}_{4} \mathrm{G}$, illegal agents still offered their services from outside, around, and within the immigration offices. A local news source, Malaysiakini, described three types of 'touts' who were involved in operating the programme. The first type operated from outside the immigration offices and charged immigrants several hundred ringgit only to be sent to, and left at, the immigration office. The second type charged MYR 200 to manage the queue at ground level before the real queue began. The third type of tout charged MYR 500 to arrange for a registration number while migrants were in the queue. The Immigration Department reiterated that there were no extra charges for registration and denied any involvement with alleged touts. ${ }^{74}$

The $\mathrm{B} 4 \mathrm{G}$ programme did not appeal to migrant workers, who had often spent large sums of money migrating to Malaysia. Many of them were reluctant to return to their home countries. Thousands of undocumented workers, especially Bangladeshis, faced problems with participating, often either due to their inability to purchase airline tickets or because they were being forced by employers to stay, resulting in their arrest after the registration deadline. ${ }^{75}$ The fines imposed (MYR 7OO) on undocumented migrants were unreasonably high for workers whose wages were far below the minimum wage of MYR 1,100 per month (as of 2019) and who were still struggling to pay off the debt incurred in the process of migrating to Malaysia in the first place. For workers' unions such as the Building and Wood Workers' and International Timber Employees Union of Peninsular Malaysia, the fines were a 'real disincentive' for poor migrants. ${ }^{76}$ The Immigration Department targeted a minimum of 70,000 arrests in 2020 in

73 '165,040 illegals repatriated under B4G programme, says Immigration D-G', Malay Mail Online, 1-1-2020. https://www.malaymail.com/news/malaysia/2020/o1/o1/immigration-d -g-165040-illegals-repatriated-under-b4g-programme/1823883 (accessed 10-7-2020).

74 Alyaa Alhadjri, 'Good intentions fall short as migrant amnesty logistics prove a nightmare', Malaysiakini, 31-12-2019. https://www.malaysiakini.com/news/505443 (accessed 107-2020).

75 Md Owasim Uddin Bhuyan, 'Undocumented Bangladeshis in Malaysia: Thousands in crisis, amnesty ends Dec 31', New Age, 15-12-2019. https://www.newagebd.net/article/936 9o/thousands-in-crisis-amnesty-ends-dec-31 (accessed 19-11-2020).

76 'RM70о too high to encourage workers to take up latest amnesty programme, says union', Free Malaysia Today, 19-7-2019. https://www.freemalaysiatoday.com/category/nation/ 2019/07/19/rm70o-too-high-to-encourage-workers-take-up-latest-amnesty-programme -says-union/ (accessed 19-11-2020). 
the post-amnesty crackdown. The nationwide crackdown implemented after the $\mathrm{B}_{4} \mathrm{G}$ deadline only penalized those who were unable to participate in $\mathrm{B}_{4} \mathrm{G} .{ }^{77}$

The $\mathrm{B} 4 \mathrm{G}$ programme also did not appeal to employers, especially those in the plantation and farming sector, which relied heavily on foreign workers. The sector experienced a lack of workers, as local workers shunned farm work. Employers criticized the government for not devising a viable solution to address the shortage of workers. Instead of addressing the underlying problem (an overreliance on foreign workers), the government repatriated undocumented workers and took serious action against employers. Many employers resort to hiring undocumented workers because hiring legal foreign workers is a difficult and cumbersome process. ${ }^{78}$

Less than one year after the conclusion of $\mathrm{B} 4 \mathrm{G}$, a new initiative, the Illegal Immigrant Recalibration Plan (16 November 2020-30 June 2021), was launched to reduce the number of undocumented migrants. Under the plan, workers were given the choice of either leaving the country or staying. The plan had two parts: the Return Recalibration Programme for migrants wishing to return home and the Labour Recalibration Programme for those wishing to be legalized. The plan targeted the participation of between 200,000 and 250,000 undocumented migrants. It was implemented by the Department without any third party and digitalization was introduced in the application process. Employers were only allowed to regularize workers who were currently employed without valid permit or those detained at the immigration detention centres. $^{79}$

Conclusions

This final section answers the three research questions posed at the beginning of this article: Why have legalization and amnesty programmes not reduced undocumented migration? What have been the limitations of the legaliza-

77 Md Owasim Uddin Bhuyan, 'Malaysian amnesty ends', New Age, 2-1-2020. https://www .newagebd.net/article/95455/malaysian-amnesty-ends (accessed 19-11-2020).

78 'Dec 31 deadline looms for illegals', Star Online, 25-12-2019. https://www.thestar.com.my/ news/nation/2019/12/25/dec-31-deadline-looms-for-illegals (accessed 10-7-2020).

79 'Govt to launch illegal immigrant recalibration plan from Nov 16', Edge Markets, 12-11-2020. https://www.theedgemarkets.com/article/govt-launch-illegal-immigrant-recalibration -plan-nov-16 (accessed 19-11-2020); Mazwin Nik Anis, 'Immigration Dept expects 20025ok illegals to participate in labour recalibration plans', Star Online, 4-12-2020. https:// www.thestar.com.my/news/nation/2020/12/o4/immigration-dept-expects-200-25ok -illegals-to-participate-in-labour-recalibration-plans (accessed 19-11-2020). 
tion and amnesty programmes implemented in Malaysia since 1989? And what changes have been introduced to the programmes since 2016? There are two reasons why the legalization approach does not correspond with the state's efforts in reducing undocumented migration. First, the legalization policy serves as a registration and surveillance tool. It merely registers existing unregistered workers by providing foreign workers with a short-term work permit and a temporary legal status. These workers would lose their legal status as documented workers if they failed to renew their work permits annually (World Bank 2013:122). With the introduction of the biometric system to register undocumented workers since 2011, legalization programmes also function as a surveillance tool. As part of the surveillance exercise, legalization programmes allow the state to obtain biometric data on undocumented workers, to keep track of them, and to improve national security. ${ }^{80}$

Second, legalization programmes are no substitute for a proper foreignworker policy. Issuing undocumented foreign workers with a temporary work permit is an ad hoc solution, which does not address labour market needs in the long run. Foreign workers are vital for economic development and the country is unable to reduce its dependence on low-skilled foreign labour. ${ }^{81}$ Similarly, the voluntary repatriation of undocumented migrants does not tackle the root causes of migrant labours working without proper documentation. The $\mathrm{B}_{4} \mathrm{G}$ programme was no substitute for a comprehensive migrant labour management policy and could not address the flawed recruitment system. Many workers became undocumented because their employers failed to renew their work permits and their recruitment agents failed to provide them with the proper documentation. ${ }^{82}$

The main limitation of the legalization and amnesty programmes is the involvement of private agents. Although the Malaysian government eliminated outsourcing and replaced agents with immigration contractors during the implementation of the Rehiring Programme and the E-Card Programme, this move was unsuccessful. Employers regarded the state-appointed immigration

8o Liz Gooch, 'Malaysia considers amnesty for illegal immigrants', New York Times, 7-6-2011. https://www.nytimes.com/2011/o6/o8/business/global/o8iht-amnestyo8.html (accessed 19-11-202O); Kong See Hoh, 'E-Card a “Tricky” option, says ME F', Sun Daily, 15-2-2017. https:// www.thesundaily.my/news/2163193 (accessed 10-7-2020).

81 Glorene A. Das, 'Temporary work permits for migrants can't substitute proper policy', Malaysiakini, 2-11-2020. https://www.malaysiakini.com/letters/549101 (accessed 19-11-20 20).

82 Trinna Leong, 'Activists blast amnesty plan for illegal workers', Straits Times, 10-8-2019. https://www.straitstimes.com/asia/se-asia/activists-blast-amnesty-plan-for-ill (accessed 10-8-2019). 
contractors as a redundant layer of bureaucracy and complained about the registration fees imposed by the contractors to legalize their workers. Employers wanted the government to simplify the process and eliminate any form of intermediary. ${ }^{83}$ The objective of eliminating agents was also frustrated by the presence of fraudulent agents and counterfeit syndicates involved in accessing the programmes illegally. Dealing directly with the Immigration Department, as demanded by employers and civil society groups, would ensure migrants' welfare, reduce the administration costs, and enhance the efficiency of the programme. ${ }^{84}$

The second limitation of the legalization and amnesty programmes is the lack of cooperation from employers. As the discussion above shows, the response rate was far below the Immigration Department's initial targets of the participation of two million workers in the Rehiring Programme and of 600,000 workers in the E-Card Programme. Errant employers did not respond to the programmes and were reluctant to register their workers. Firms were willing to risk violating the immigration laws. The penalties imposed did not serve as an effective deterrent as there is a perception that errant employers can get away with breaking the law. Law-abiding employers, who hire local workers and pay the minimum wage, are in a disadvantageous position when competing with companies using undocumented workers. In the 'race to the bottom', employers resort to the readily available pool of undocumented workers in the country, excessively brought in by private recruitment agencies (Low 2020:38). Within the context of cost-cutting practices, it is problematic to let employers be the gatekeepers of the legal statuses of workers. Under the sponsorshipbased immigration system, foreign workers are dependent on their employer to retain their legal immigration status (Nah 2012:498). In their role as gatekeepers, employers are helped by agents. Employers and agents are accountable for the undocumented status of the employed foreign workers. Making employers gatekeepers raises concerns when migrants are at 'the mercy of the agents and employers to be [documented] and remain documented' ${ }^{85}$

83 'DAP: Agents make millions for "paper-shifting” at immigration', Free Malaysia Today, 22-32017. https://www.freemalaysiatoday.com/category/nation/2017/o3/22/dap-agents-make -millions-for-paper-shifting-at-immigration/ (accessed 10-7-2020); Rahimy Rahim, 'Race to legalise foreign workers', Star Online, 27-8-2017. https://www.thestar.com.my/news/ nation/2018/08/27/race-to-legalise-foreign-workers-but-employers-are-in-a-bind-as -vendors-are-unsure-of-contract-statu\#JKuvwsjbvYzgf6Gh.99 (accessed 10-8-2019).

84 'Immigration Department detects false E-Cards', New Straits Times, 5-7-2017. https://www .nst.com.my/news/nation/2017/07/254655/immigration-department-detects-false -e-cards (accessed 10-8-2019).

85 Md Owasim Uddin Bhuyan, 'Malaysian amnesty ends', New Age, 2-1-2020. https://www .newagebd.net/article/95455/malaysian-amnesty-ends (accessed 19-11-2020). 
Third, legalization and amnesty programmes were not of benefit to the undocumented migrants and subjected them to exploitations. From a migrant rights perspective, undocumented migrants bear the brunt of the financial burden of participating in the programmes. Tenaganita perceived the imposed legalization fees and voluntary repatriation fines on undocumented immigrants as treating immigrants as an 'additional source of income' 86 and as a way for the government to profit from the programmes. The immigrants had to bear all the costs, had to go through the complex application procedures, and were subject to corrupt practices by the outsourced companies appointed to run the programme with no recourse to justice. ${ }^{87}$

Finally, changes introduced to the legalization and amnesty programmes, especially the use of biometrics and the digitalization of the application process, have improved certain implementation and monitoring aspects. Despite the initiation of these programmes, undocumented migrants have continued to exist because these programmes have not addressed the root causes of why migrants are working without proper documentation, namely that employers engage in their 'race to the bottom' by hiring undocumented workers who are dependent on their employers and agents as the gatekeepers of their legal immigration status. The nature of the legalization and amnesty regime has remained the same: addressing the aftermath of the influx, pardoning those violating the Immigration Act, victimizing the law-abiding employers, and penalizing migrants who ended up as undocumented through no fault of their own. The policies of legalization and amnesty will continue to be utilized as long as Malaysia continues to struggle with recruiting foreign workers for the labour market while at the same time controlling undocumented migration.

\section{Acknowledgements}

The author is grateful to Freek Colombijn as the editor-in-chief of the journal and to the anonymous reviewers for their invaluable insights and constructive critiques on the earlier version of this article. Their comments have been tremendously helpful in improving the overall structure, hypothetical inquiry,

86 'Stop using migrants as ATM s, Tenaganita tells govt', Malaysiakini, 19-7-2019, https://www .malaysiakini.com/news/484542 (accessed 10-8-2019).

87 Glorene A. Das, 'Temporary work permits for migrants can't substitute proper policy', Malaysiakini, 2-11-2020. https://www.malaysiakini.com/letters/549101 (accessed 19-11-20 20); Eileen Ng, 'Activists fear abuse in Malaysian labor amnesty', Irrawaddy, 29-7-2011. https://www2.irrawaddy.com/article.php?art_id=21793 (accessed 19-11-2020). 
discussion, and research findings. This research was supported by Universiti Sains Malaysia (Bridging Funds 304.PJJAU H.6316524).

\section{References}

Abella, M. and P. Martin (2016). Guide on measuring migration policy impacts in ASEAN. Bangkok: ILO Regional Office for Asia and the Pacific.

Anderson, J.T. (2021). 'Managing labour migration in Malaysia: Foreign workers and the challenges of "control" beyond liberal democracies', Third World Quarterly 42-1: 86104.

Ang, J.W., A. Murugasu and Y.W. Chai (2018). 'Low-skilled foreign workers' distortions to the economy'. Kuala Lumpur: Bank Negara Malaysia. [Working Paper 14.]

Arifianto, A.R. (2009). 'The securitization of transnational labor migration: The case of Malaysia and Indonesia', Asian Politics \& Policy 1-4:613-30.

Dollah, Ramli and Kamarulnizam Abdullah (2015). 'Serbuan, pengusiran dan krisis tenaga kerja di Malaysia: Dilema negara dan dasar tenaga kerja asing di Sabah', Borneo Research Journal 9:19-44.

Economic Planning Unit, Prime Minister's Department (2015). Eleventh Malaysia Plan 2016-2020: Anchoring growth on people. Putrajaya: Prime Minister's Department.

Garcés-Mascareñas, B. (2012). Labour migration in Malaysia and Spain:Markets, citizenship and rights. Amsterdam: Amsterdam University Press.

Harkins, B. (2016). Review of labour migration policy in Malaysia: Tripartite action to enhance the contribution of labour migration to growth and development in ASEAN. Bangkok: ILo Regional Office for Asia and the Pacific.

Hedman, E.L.E. (2008). 'Refuge, governmentality and citizenship: Capturing "illegal migrants" in Malaysia and Thailand', Government and Opposition 43-2:358-83.

Jones, S. (2000). Making money off migrants: The Indonesian exodus to Malaysia. Hong Kong: Asia 2000 Ltd.

Kassim, A. (2014). 'Recent trends in transnational population inflows into Malaysia: Policy, issues and challenges', Malaysian Journal of Economic Studies 51-1:9-28.

Kassim, A. and R. Mat Zin (2011). 'Policy on irregular migrants in Malaysia: An analysis of its implementation and effectiveness'. [PIDs Discussion Paper Series No. 2011-34.]

Kaur, A. (2014). 'Managing labour migration in Malaysia: Guest worker programs and the regularisation of irregular labour migrants as a policy instrument', Asian Studies Review 38-3:345-66.

Kaur, A. (2015). 'Malaysia: Labour migration, irregular movements and regional policies', in: J. Pietsch and M.A. Clark (eds), Migration and integration in Europe, Southeast Asia, and Australia. A comparative perspective, pp. 75-98. Amsterdam: Amsterdam University Press. 
Khanazah Research Institute (2018). 'The state of household 2018: Different realities'. Kuala Lumpur: Khazanah Research Institute. [Report.]

Lee, Hwok-Aun (2017). 'Labour policies and institutions in the Eleventh Malaysia Plan: Aiming high, falling short', Journal of Southeast Asian Economies 34-3:552-70.

Liow, J. (2003). 'Malaysia's illegal Indonesian migrant labor problem: In search of solutions', Contemporary Southeast Asia 25-1:44-64.

Low, C.C. (2020). 'De-commercialization of the labor migration industry in Malaysia', Southeast Asian Studies 9-1:27-65.

Nah, A.M. (2012). 'Globalisation, sovereignty and immigration control: The hierarchy of rights for migrant workers in Malaysia', Asian Journal of Social Science 40-4:4865 o8.

Nah, A.M. (2015). 'Illegality and its uncertainties: Immigration detention in Malaysia', in: A. Nethery and S.J. Silverman (eds), Immigration detention: The migration of a policy and its human impact, pp. 125-34. London: Routledge.

Narayanan, S. and Y.W. Lai (2005). 'The causes and consequences of immigrant labour in the construction sector in Malaysia', International Migration 43-5:31-57.

Nesadurai, H.E.S (2013). 'Malaysia's conflict with the Philippines and Indonesia over labour migration: Economic security, interdependence and conflict trajectories', The Pacific Review 26-1:89-113.

Ullah, A.K.M. Ahsan (2013). 'Irregular migrants, human rights and securitization in Malaysia: An analysis from a policy perspective', in: C. Tazreiter and S.Y. Tham (eds), Globalization and social transformation in the Asia-Pacific: The Australian and Malaysian experience, pp. 178-88. Basingstoke: Palgrave Macmillan.

World Bank (2013). 'Immigration in Malaysia: Assessment of its economic effects and a review of the policy and system'. Washington, DC: World Bank Group. [Report.]

World Bank (2015). 'Malaysia economic monitor: Immigrant labour'. Washington, DC: World Bank Group. [Report.] 